\title{
Influence of polyethylene glycol on in vitro gas production profiles and microbial protein synthesis of some shrub species ${ }^{\text {t3 }}$
}

\author{
M. Guerrero a,b,e, M.A. Cerrillo-Soto ${ }^{\text {a,f,*, R.G. Ramírez }}{ }^{\text {b }}$ A.Z.M. Salem ${ }^{c, e, * *}$, H. González ${ }^{\text {d }}$, \\ A.S. Juárez-Reyes ${ }^{\mathrm{a}, \mathrm{f}}$ \\ a Facultad de Medicina Veterinaria y Zootecnia, Universidad Juárez del Estado de Durango, Km 11.5 Carretera Durango-Mezquital, Durango, 34280, Mexico \\ b Facultad de Ciencias Biológicas, Alimentos. Universidad Autónoma de Nuevo León, Avenida Universidad, S/N, San Nicolás de los Garza, Nuevo León, 66450, \\ Mexico \\ c Facultad de Medicina Veterinaria y Zootecnia, Universidad Autónoma del Estado de México, Estado de Mexico, Mexico \\ d Facultad de Ciencias Forestales, Universidad Autónoma de Nuevo León, Apartado Postal 41, Linares, Nuevo León, 67700, Mexico \\ e Faculty of Agriculture (El-Shatby), Alexandria University, Egypt \\ ${ }^{\mathrm{f}}$ Red Internacional de Nutrición y Alimentación de Rumiantes, Mexico
}

\section{A R T I C L E I N F O}

\section{Keywords:}

Shrubs

Polyethylene glycol

In vitro gas production

Microbial efficiency

\begin{abstract}
A B S T R A C T
The aim was to determine effects of addition of polyethylene glycol (PEG) on in vitro gas production and microbial protein synthesis of the shrub species Acacia constricta, Acacia shaffneri, Calliandra eriophylla, Condalia lycioides, Cordia parvifolia, Larrea tridentata and Mimosa biuncifera, which are commonly consumed by grazing small ruminants in semiarid regions of Mexico despite the abundance of tannins in their foliage. Three individual samples (a minimum of 10 plants of each) of each shrub species were collected from different areas and prepared for chemical and secondary metabolite analysis. In vitro evaluations for each sample of each shrub species were completed in three incubation runs in different weeks using calibrated glass syringes in a $7 \times 2$ factorial design (i.e., 7 shrub species $\times 2$ treat ments with or without PEG). In vitro gas production after 24 and $96 \mathrm{~h}$, partitioning factor $(\mathrm{PF})$, metabolizable energy (ME) content, efficiency of microbial protein synthesis (EMPS) and volatile fatty acids (VFA) were determined. A shrub species $\times$ PEG interaction $(\mathrm{P}<0.05)$ only occurred for some VFA, such as $\mathrm{C} 3, \mathrm{C} 4, \mathrm{C} 4 \mathrm{i}$ and $\mathrm{C} 5 \mathrm{i}$, concentrations. Relative to control, addition of PEG increased $(\mathrm{P}<0.05)$ the concentrations of individual VFA in $A$. shaffneri, C. lycioides and $C$. parvifolia. Interactions between shrub and $\mathrm{PEG}$ occurred $(\mathrm{P}<0.001)$ for all gas production parameters (i.e., $b, k, \mathrm{IVGP}_{24}, \mathrm{IVGP}_{48}$ ). The fractional rate of gas production and IVGP ${ }_{24 \mathrm{~h}}$ were highest in $A$. constricta and lowest $(\mathrm{P}<0.001)$ in $A$. shaffneri. L. tridentata had the highest $\mathrm{PF}$ and $C$. lycioides the lowest. $A$. constricta had the highest ME content. Purine content and EMPS differed (shrubs $\times$ PEG; P<0.001) among shrubs. Microbial protein synthesis was highest in M. biuncifera and lowest in C. eriophylla, while total VFA were highest in C. eriophylla. Incorporation of PEG increased $(\mathrm{P}<0.001)$ in vitro fermentation parameters and ME content with $L$. tridentata and $C$. lycioides being the highest. PEG also promoted
\end{abstract}

\footnotetext{
Abbreviations: ADFom, acid detergent fiber expressed exclusive of residual ash; CP, crude protein; CT, condensed tannins; DM, dry matter; EE, ether extract; EMPS, efficiency of microbial protein synthesis; ME, metabolizable energy; NDFom, neutral detergent fiber assayed without $\alpha$-amylase and expressed exclusive of residual ash; PEG, polyethylene glycol; PF, partitioning factor; VFA, volatile fatty acids.

This paper is part of the special issue entitled: Plant Bioactive Compounds in Ruminant Agriculture - Impacts and Opportunities, Guest Edited by A.Z.M. Salem and S. López, and Editor for Animal Feed Science and Technology, P.H. Robinson.

* Corresponding author at: Facultad de Medicina Veterinaria y Zootecnia, Universidad Juárez del Estado de Durango, Km 11.5 Carretera DurangoMezquital, Durango, 34280, Mexico. Tel.: +52 618 8189932; fax: +52 6188189932.

** Corresponding author at: Facultad de Medicina Veterinaria y Zootecnia, Universidad Autónoma del Estado de Mexico, Estado de Mexico, Mexico. Tel.: +521722 29655 42; fax: +5217221806194.

E-mail addresses: acerrillos@terra.com.mx (M.A. Cerrillo-Soto), asalem70@yahoo.com (A.Z.M. Salem).
} 
reductions in the EMPS and PF values. In vitro fermentation variables such as fractional rate of gas production, VFA concentrations and EMPS support the potential of A. constricta, $C$. parvifolia and $M$. biuncifera as protein and energy sources for small ruminants in semiarid regions of North Mexico. Increments in gas production in these shrub species confirmed the affinity of PEG to bind condensed tannins and reduce EMPS.

(c) 2012 Elsevier B.V. All rights reserved.

\section{Introduction}

Browse constitutes an essential component of the diet of range ruminants in dry areas with prolonged periods of drought when available herbaceous species senesce and have insufficient quality and/or quantity to meet their maintenance nutrient requirements (Parissi et al., 2005; Salem et al., 2007). High crude protein (CP) content, digestible nutrients, minerals and a substantial contribution to the diet selected by small grazing ruminants, up to $820 \mathrm{~g} / \mathrm{kg}$, support the relevance of browse to ruminant nutrition (Ramirez, 1999; Sanon et al., 2008).

Many native browse species have been undervalued because of insufficient knowledge of their feeding value and for their often high content of tannins, which may be detrimental to animal performance (Min et al., 2003). The nutritive value of feeds utilized in ruminant nutrition are commonly estimated by the concentrations of chemical components, and the rates and extents of nutrient digestion (Hamid et al., 2007). The in vitro gas production procedure has become a useful tool to study potential rumen degradation of ruminant feeds (Getachew et al., 2002; Salem et al., 2007). This method allows estimation of how much substrate is used to produce volatile fatty acids (VFA) and the energetic value of browse, as well as to determine the amount of substrate truly fermented which is converted into microbial protein (Blümmel et al., 2003; Salem et al., 2007). Furthermore, when investigating plants containing secondary compounds, it is crucial to consider effects of such vegetative species on rumen microbial fermentation, making the in vitro gas production technique valuable when assessing the potential of tannin rich browse in ruminant nutrition (Salem et al., 2007; Norman et al., 2010).

Polyethylene glycol (PEG), a tannin complexing agent, has the potential to reduce phenolic related anti-nutritive effects in browse plants by forming tannin-PEG complexes (Khazaal et al., 1996), and has been used to mitigate adverse effects of secondary compounds on rumen fermentation. Addition of PEG to high tannin browse species increased in vitro gas production, ammonia $\mathrm{N}$ concentration and short chain fatty acid production, although microbial N production and efficiency of microbial protein synthesis decreased (Getachew et al., 2001; Salem et al., 2007).

Studies related to use of gas procedures to estimate rumen fermentation of individual native browses from semiarid regions of North Mexico are scarce. Thus, our objective was to evaluate effects of PEG on in vitro fermentation profiles and partitioning of fermentation products of native browses selected by goats in semiarid regions.

\section{Materials and methods}

\subsection{Site and sampling procedures}

The study was completed at the Facultad de Medicina Veterinaria y Zootecnia of the Universidad Juárez del Estado de Durango, in Durango (México). Foliage samples from Acacia constricta, Acacia shaffneri, Calliandra eriophylla, Condalia lycioides, Cordia parvifolia, Larrea tridentata and Mimosa biuncifera were collected from Cuencamé county of the state of Durango located at $24^{\circ} 55^{\prime} 38^{\prime \prime} \mathrm{LN}$ and $103^{\circ} 48^{\prime} 21^{\prime \prime}$ LO. The site has a dry climate with total annual rainfall of $450 \mathrm{~mm}$, annual mean temperature of $21^{\circ} \mathrm{C}$ and an altitude of $1580 \mathrm{~m}$ above sea level. The main soils types in the study area are regosol, vertisol, rendzina, xerosol and litosol (INEGI, 2006).

Three samples of at least 10 plants of each within each shrub species were collected from different areas and prepared for chemical and secondary metabolite analysis. Leaves, petioles and thin twigs were manually harvested from different parts of the plant at the optimum stage of vegetation, which was April and May of 2006 and 2007 . Samples were dried at $55^{\circ} \mathrm{C}$ for $48 \mathrm{~h}$, ground to pass a $1 \mathrm{~mm}$ screen in a Willey mill and stored in sealed dark containers for later analyses.

\subsection{Chemical composition}

The N (\#954.01), ether extract (EE; \#929.29) and ash (\#938.08) contents were determined as described by AOAC (1997). The neutral detergent fiber (NDFom), acid detergent fiber(ADFom), and lignin(sa) determinations were completed following Van Soest et al. (1991). Condensed tannin (CT) contents were determined using the butanol-HCl procedure and results are as leucocyanidin equivalents (Makkar, 2003a,b).

\subsection{In vitro gas production}

Three incubation runs were conducted for each sample within each shrub species. The rate and extent of in vitro gas production from shrub foliages were obtained from a $96 \mathrm{~h}$ incubation (Menke and Steingass, 1988) in which triplicate $500 \mathrm{mg}$ samples were incubated in $100 \mathrm{ml}$ calibrated glass syringes. Effects of PEG on in vitro gas production was determined 
by addition of $1 \mathrm{~g}$ of PEG (6000) in a different set of three syringes within the same incubation run. The culture medium contained a buffer solution comprising mainly $\mathrm{Na}_{2} \mathrm{HPO}_{4}$ and $\mathrm{NaHCO}_{3}$, with smaller amounts of $\mathrm{MnCl}_{2}, \mathrm{CaCl}_{2}, \mathrm{CoCl}_{2}$ and $\mathrm{FeCl}_{3}$ and saturated with $\mathrm{CO}_{2}$ at $39{ }^{\circ} \mathrm{C}$. The medium was reduced by addition of a reducing agent. Forty milliliters of a mixture of rumen fluid:buffer solution in a 1:3 ratio was added to each syringe. Inoculum was obtained from three Rambouillet fistulated sheep $(60 \pm 3.7 \mathrm{~kg}$ live weight) fed alfalfa hay and a concentrate (750:250) at a maintenance metabolizable energy (ME) level. Procedures were approved by the Animal Care and Use Committee of the Universidad Juárez del Estado de Durango.

A total of 378 syringes during the incubation ( 3 syringes of each triplicate sample within each of the 7 tree species with 2 treatments (with or without PEG) in 3 incubation runs) with two syringes containing no substrate were included in each incubation as blanks. Syringes were vertically positioned in a water bath at $39^{\circ} \mathrm{C}$. Gas production was registered at 3 , 6 , $9,12,24,48,72$ and $96 \mathrm{~h}$. Data were adjusted to the model $G=A\left(1-e^{-c(t-L)}\right)$ as proposed by France et al. (2000): where $G$ $(\mathrm{ml})$ denotes cumulative gas production at time $t ; b(\mathrm{ml})$ is asymptotic gas production; $c(/ \mathrm{h})$ is the fractional rate of gas production from the slowly fermentable feed fraction $b$, and $L(\mathrm{~h})$ is the lag time before fermentation begins. In vitro gas production parameters were estimated using PROC NLIN (Cody and Smith, 1997).

A partitioning factor (PF) was determined after $24 \mathrm{~h}$ of incubation from another run, with gas volume recordings after 3 , $6,9,12$ and $24 \mathrm{~h}$ of incubation. At this time the incubation was terminated and the entire syringe contents were transferred to centrifuge tubes. Syringes were rinsed with distilled water and shaken each time to remove residual particles. Contents were centrifuged at $20,000 \times \mathrm{g}$ for $30 \mathrm{~min}$ at $4{ }^{\circ} \mathrm{C}$. The supernatant fraction was carefully discarded and the pellet was washed again with distilled water and re-centrifuged. The entire residue was placed into filter bags (ANKOM ${ }^{\circledR}$, Macedom, NY, USA) and refluxed with neutral detergent solution using the $\mathrm{ANKOM}^{\circledR}$ Fiber Analyzer to determine true in vitro DM degradability (g/kg DM). Our $24 \mathrm{~h}$ PF was calculated as the ratio of $\mathrm{mg}$ substrate truly degraded/ml gas produced according to Blümmel et al. (1997). The ME was calculated from in vitro gas production in accordance with the equation (Menke and Steingass, 1988):

$$
\mathrm{ME}(\mathrm{MJ} / \mathrm{kg} \mathrm{DM})=2.20+0.136 \mathrm{GP}_{24 \mathrm{~h}}+0.057 \mathrm{CP}+0.0029 \mathrm{EE}^{2}
$$

where $\mathrm{GP}_{24 \mathrm{~h}}$ is gas production after $24 \mathrm{~h}$ of incubation ( $\mathrm{ml}$ gas $/ 0.5 \mathrm{~g} \mathrm{DM}$ ); CP is the crude protein ( $\mathrm{g} / \mathrm{kg} \mathrm{DM}$ ); EE is the ether extract (g/kg DM).

\subsection{Microbial protein synthesis and volatile fatty acid determination}

After $24 \mathrm{~h}$ of incubation, contents of another set of syringes were transferred to centrifuge tubes and centrifuged at $20,000 \times \mathrm{g}$ for $30 \mathrm{~min}$ at $4{ }^{\circ} \mathrm{C}$ and the supernatant saved. The pellet was washed with distilled water, centrifuged again and lyophilized overnight and residual moisture was removed by oven drying at $55^{\circ} \mathrm{C}$ overnight. Blank pellet weights were determined by centrifugation of $3 \times 40 \mathrm{ml}$ of the mixture of rumen fluid:buffer solution at $0 \mathrm{~h}$ of incubation. Purines in residue were estimated according to Makkar (2003a,b). $5 \mathrm{ml}$ of supernatant were placed in tubes containing $1 \mathrm{ml}$ metaphosphoric acid $(26.51 \mathrm{~g} / 100 \mathrm{ml}(\mathrm{w} / \mathrm{v}))$, centrifuged at $20,000 \times \mathrm{g}$ for $30 \mathrm{~min}$ at $4{ }^{\circ} \mathrm{C}$ and stored for determination of volatile fatty acids (VFA) in a Perkin-Elmer (AutoSystem XL, Waltham, MA, USA) gas chromatograph with a $30 \mathrm{~cm}$ long, $0.25 \mathrm{~mm}$ diameter, PE-WAX column.

\subsection{Statistical analyses}

Chemical composition and condensed tannin contents were analyzed according to a completely randomized design (Cody and Smith, 1997) using GLM of SAS (2002). Mean differences were separated using Tukey’s test (Steel and Torrie, 1980). Data on in vitro ruminal fermentation parameters and microbial protein synthesis of each of the three runs within sample replicate were averaged and used as the mean value of each individual sample within shrub species ( 3 samples) were the experimental unit (Udén et al., 2012). Data were analyzed according to a $7 \times 2$ factorial design ( 7 shrub species $\times 2$ treatments with or without PEG) using the GLM option of SAS with the statistical model:

$$
Y_{i j k}=\mu+P_{i}+S_{j}+(P S)_{i j}+\varepsilon_{i j k}
$$

where $Y_{i j k}$ is the measured parameter of the $i j k$ treatment, $\mu$ the overall mean, $P_{i}$ the effect of PEG, $S_{j}$ the effect of species, $(P S)_{i j}$ the interaction of treatment and species and $\varepsilon_{i j k}$ is the residual error term.

\section{Results}

Crude protein (CP) content of the foliages ranged from 168 (A. constricta) and 155 (A. shaffneri and M. biuncifera) to $109 \mathrm{~g} / \mathrm{kg}$ DM (C. eriophylla) (Table 1). Neutral detergent fiber (NDFom) and acid detergent fiber (ADFom) were highest in A. shaffneri (574 and $341 \mathrm{~g} / \mathrm{kg}$, respectively). L. tridentata had the lowest ADFom and lignin(sa) values (257 and $35 \mathrm{~g} / \mathrm{kg}$, respectively). The concentration of condensed tannins (CT) fluctuated from $0.16 \mathrm{~g} / \mathrm{kg}$ DM in C. parvifolia to $29 \mathrm{~g} / \mathrm{kg}$ DM in C. lycioides. Ash content was highest in C. parvifolia at $163 \mathrm{~g} / \mathrm{kg}$. 
Table 1

Chemical composition ( $\mathrm{g} / \mathrm{kg} \mathrm{DM})$ of shrubs.

\begin{tabular}{|c|c|c|c|c|c|c|}
\hline & $\mathrm{CP}$ & NDFom & ADFom & Lignin (sa) & $\mathrm{CT}$ & Ash \\
\hline Acacia constricta & $168^{a}$ & $345^{d}$ & $215^{\mathrm{d}}$ & $86^{d}$ & $3^{\mathrm{cd}}$ & $73^{d}$ \\
\hline Acacia shaffneri & $155^{\mathrm{a}}$ & $574^{\mathrm{a}}$ & $341^{\mathrm{a}}$ & $105^{b c}$ & $10^{c}$ & $70^{d}$ \\
\hline Calliandra eriophylla & $109^{\mathrm{e}}$ & $433^{\mathrm{bc}}$ & $293^{c}$ & $115^{\mathrm{b}}$ & $23^{a b}$ & $114^{\mathrm{b}}$ \\
\hline Condalia lycioides & $143^{\mathrm{bc}}$ & $336^{\mathrm{d}}$ & $193^{e}$ & $99^{c}$ & $29^{a}$ & $87^{c}$ \\
\hline Cordia parvifolia & $125^{\mathrm{d}}$ & $413^{c}$ & $316^{\mathrm{b}}$ & $105^{b c}$ & $0.2^{\mathrm{d}}$ & $163^{\circ}$ \\
\hline Larrea tridentata & $131^{\mathrm{cd}}$ & $257^{e}$ & $165^{f}$ & $35^{\mathrm{e}}$ & $19^{\mathrm{b}}$ & $88^{c}$ \\
\hline Mimosa biuncifera & $155^{\mathrm{ab}}$ & $467^{\mathrm{b}}$ & $328^{a b}$ & $139^{a}$ & $27^{\mathrm{a}}$ & $59^{e}$ \\
\hline SEM & 3.5 & 2.3 & 4.5 & 2.4 & 0.28 & 1.2 \\
\hline
\end{tabular}

Means within columns with different letters (a,b,c,d,e) differ at P<0.05. CP: crude protein; NDFom: neutral detergent fiber; ADFom: acid detergent fiber; CT: condensed tannins.

A shrub $\times$ PEG interaction $(\mathrm{P}<0.05)$ only occurred for some VFA (i.e., $\mathrm{C} 3, \mathrm{C} 4, \mathrm{C} 4 \mathrm{i}, \mathrm{C} 5 \mathrm{i}$ ) concentrations. All other VFA were highest $(\mathrm{P}<0.01)$ for $C$. eriophylla. Lowest values $(\mathrm{P}<0.05)$ for $\mathrm{C} 4$ were for $A$. shaffneri, while $C$. lycioides had the lowest $(\mathrm{P}<0.05)$ $\mathrm{C} 2, \mathrm{C} 4 \mathrm{i}$ and $\mathrm{C} 5 \mathrm{i}$. Addition of PEG increased $(\mathrm{P}<0.05)$ concentrations of some VFA in A. shaffneri, $\mathrm{C}$. eriophylla and C. parvifolia (Table 2).

Interactions between shrub and PEG occurred ( $\mathrm{P}<0.001)$ in all gas production parameters $\left(i . e ., b, k, \mathrm{IVGP}_{24}, \mathrm{IVGP}_{48}, L\right)$. Fraction $b$ in all shrubs, except $C$. eriophylla and $C$. parvifolia increased $(P<0.01)$ with addition of $P E G$, and it also increased fraction $b$ in all shrubs. In addition, PEG increased ( $P<0.001)$ IVGP at 24 and $48 \mathrm{~h}$ of incubation in all shrubs except $C$. parvifolia and $L$. tridentata, and decreased $(\mathrm{P}<0.001) L$ in the same species (Table 2$)$.

Purine content and EMPS (calculated as mol purines/mol VFA) differed (i.e., shrub $\times$ PEG; P<0.001) among foliages. Addition of PEG reduced $(\mathrm{P}<0.001)$ purine concentrations as well as EMPS, except for $C$. parvifolia EMPS, and also reduced EMPS in $M$. biuncifera (Table 2).

The PF, IVDMD and ME values varied (shrub $\times$ PEG; P<0.001) among shrubs, with PEG decreasing $(\mathrm{P}<0.001)$ PF in all shrubs. The ME content ranged from 5 to $8.3 \mathrm{MJ} / \mathrm{kg}$, and PEG increased $(\mathrm{P}<0.001)$ the ME contents of all shrubs (Table 2 ).

\section{Discussion}

\subsection{Foliage species}

The chemical composition of our shrubs was consistent with those previously reported from semiarid regions of Mexico (Ramírez-Orduña et al., 2003). The CP content of shrub species in our study were above $100 \mathrm{~g} / \mathrm{kg}$ DM, which supports the suggestion that their foliage might be considered a suitable supplement to low quality diets during harsh conditions (Camacho et al., 2010). Furthermore, lower levels of NDFom than those reported for other shrub species in northern (Ramírez and Lara, 1998) and central México (Pinos-Rodríguez et al., 2007) suggest a relatively high availability of soluble carbohydrates in our shrubs (Narvaez et al., 2010). In contrast, ADF > $200 \mathrm{~g} / \mathrm{kg}$ DM might be mostly due to elevated lignin. Values of CT in shrub species varied from 0.16 to $29 \mathrm{~g} / \mathrm{kg}$ DM. The content of tannins in tree and shrub foliage may range from 15 to $300 \mathrm{~g} / \mathrm{kg} \mathrm{DM}$ (Leinmüller and Menke, 1990), and factors related to physiological changes, soil type, fertility and water supply may affect levels of tannins in plants (Ammar et al., 2004).

\section{2. $P E G$ addition}

The higher gas production of all shrubs with PEG demonstrates the affinity of PEG to bind tannins (Makkar et al., 1995). The detrimental effect of phenolic compounds relates to impaired feed digestibility and nutrient utilization, a negative effect mediated by the interaction between tannins, microbes and non-starch-polysaccharides in animal feeds, and such interactions may influence the functionality of ruminal microbes. Increased gas production with PEG in M. biuncifera, A. shaffneri and $C$. lycioides likely promoted higher nutrient availability to rumen micro-organisms, especially available $\mathrm{N}$. This is also supported by a positive effect of PEG on rate of in vitro gas production, which is consistent with reports of others (Pinto et al., 2002; Salem et al., 2007). However, PEG did not promote increments in gas production in C. eriophylla, which had a high CT content compared to our other shrubs, which might be the consequence of factors other than tannins contained in C. eriphylla which might have limited fermentation in vitro.

Quantification of concentrations of the main VFA produced from digestion of carbohydrates in the rumen provides information to compare the nutritional value of ruminant feeds (Markantonatos et al., 2008). Gas production from a variety of feeds incubated in vitro has been closely related to production of VFA based on carbohydrate fermentation (Getachew et al., 2002). According to Jones et al. (2000), PEG might increase CP digestibility, but not IVDMD. In addition, it has been suggested that PEG increases microbial protein synthesis (Getachew et al., 2002). Monteforte-Briceño et al. (2005) noted that 
Table 2

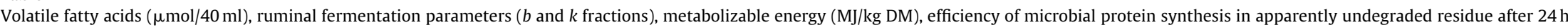

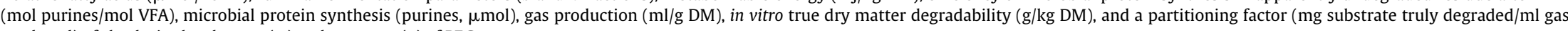
produced) of shrubs in the absence $(-)$ and presence $(+)$ of PEG.

\begin{tabular}{|c|c|c|c|c|c|c|c|c|c|c|c|c|c|c|c|c|c|c|}
\hline & \multicolumn{14}{|c|}{ Shrub (S) } & \multirow{3}{*}{ SEM } & \multicolumn{3}{|l|}{$P$} \\
\hline & \multicolumn{2}{|c|}{ A. constricta } & \multicolumn{2}{|c|}{ A. shaffneri } & \multicolumn{2}{|c|}{ C. eriophylla } & \multicolumn{2}{|c|}{ C. lycioides } & \multicolumn{2}{|c|}{ C. parvifolia } & \multicolumn{2}{|c|}{ L. tridentata } & \multicolumn{2}{|c|}{ M. biuncifera } & & \multirow[t]{2}{*}{ Shrub } & \multirow[t]{2}{*}{ PEG } & \multirow[t]{2}{*}{$\mathrm{S} \times \mathrm{P}$} \\
\hline & - & + & - & + & - & + & - & + & - & + & - & + & - & + & & & & \\
\hline \multicolumn{19}{|c|}{ Ruminal fermentation parameters } \\
\hline Total VFA & 660 & 716 & $430^{\mathrm{b}}$ & $612^{\mathrm{a}}$ & $831^{\mathrm{b}}$ & $946^{\mathrm{a}}$ & 520 & 544 & 713 & 604 & 478 & 519 & 588 & 597 & 25.0 & $<0.01$ & ns & $<0.05$ \\
\hline $\mathrm{C} 2$ & 446 & 471 & 310 & 404 & 534 & 582 & 454 & 367 & 473 & 449 & 325 & 356 & 436 & 416 & 18.8 & $<0.01$ & ns & ns \\
\hline C3 & 103 & 113 & $40^{\mathrm{b}}$ & $82^{\mathrm{a}}$ & $173^{\mathrm{b}}$ & $191^{\mathrm{a}}$ & 66 & 58 & $47^{\mathrm{b}}$ & $102^{\mathrm{a}}$ & 84 & 103 & 74 & 86 & 6.5 & $<0.01$ & $<0.05$ & $<0.05$ \\
\hline C4 & 72 & 68 & 37 & 57 & 73 & 89 & 54 & 55 & 54 & 60 & 39 & 35 & 38 & 47 & 3.1 & $<0.01$ & $<0.05$ & ns \\
\hline C4i & 16 & 16 & $13^{\mathrm{b}}$ & $18^{\mathrm{a}}$ & $28^{\mathrm{b}}$ & $32^{\mathrm{a}}$ & 8 & 5 & $14^{\mathrm{a}}$ & $21^{\mathrm{b}}$ & 5 & 6 & 14 & 15 & 1.5 & $<0.01$ & $<0.05$ & $<0.05$ \\
\hline C5i & 18 & 19 & $10^{\mathrm{b}}$ & $13^{\mathrm{a}}$ & $20^{\mathrm{b}}$ & $24^{\mathrm{a}}$ & 10 & 6 & $11^{\mathrm{b}}$ & $17^{\mathrm{a}}$ & 8 & 9 & $9^{\mathrm{b}}$ & $12^{\mathrm{a}}$ & 0.8 & $<0.01$ & $<0.01$ & $<0.05$ \\
\hline C5 & 22 & 22 & 17 & 19 & 24 & 26 & 8 & 5 & 17 & 20 & 16 & 17 & 12 & 14 & 0.8 & $<0.01$ & ns & ns \\
\hline \multicolumn{19}{|c|}{ Gas production parameters } \\
\hline$b$ & $204^{\mathrm{b}}$ & $223^{a}$ & $162^{\mathrm{b}}$ & $173^{\mathrm{a}}$ & $185^{a}$ & $152^{\mathrm{b}}$ & $187^{\mathrm{b}}$ & $214^{\mathrm{a}}$ & 224 & 222 & $145^{\mathrm{b}}$ & $216^{a}$ & $181^{\mathrm{b}}$ & $211^{\mathrm{a}}$ & 2.5 & $<0.01$ & $<0.01$ & $<0.01$ \\
\hline$k$ & $0.078^{\mathrm{b}}$ & $0.111^{\mathrm{a}}$ & $0.019^{b}$ & $0.033^{\mathrm{a}}$ & $0.034^{\mathrm{b}}$ & $0.059^{\mathrm{a}}$ & $0.053^{\mathrm{b}}$ & $0.083^{\mathrm{a}}$ & 0.060 & 0.060 & $0.034^{\mathrm{a}}$ & $0.020^{\mathrm{b}}$ & $0.045^{\mathrm{b}}$ & $0.072^{\mathrm{a}}$ & 0.0020 & $<0.01$ & ns & $<0.01$ \\
\hline Gas $24 \mathrm{~h}$ & $173^{\mathrm{b}}$ & $207^{a}$ & $60^{\mathrm{b}}$ & $95^{\mathrm{a}}$ & $103^{\mathrm{b}}$ & $114^{\mathrm{a}}$ & $135^{\mathrm{b}}$ & $185^{\mathrm{a}}$ & 171 & 170 & 81 & 82 & $120^{\mathrm{b}}$ & $172^{\mathrm{a}}$ & 4.3 & $<0.01$ & $<0.01$ & $<0.01$ \\
\hline Gas $48 \mathrm{~h}$ & $199^{\mathrm{b}}$ & $221^{\mathrm{a}}$ & $98^{\mathrm{b}}$ & $138^{\mathrm{a}}$ & 148 & 142 & $173^{\mathrm{b}}$ & $210^{\mathrm{a}}$ & 211 & 210 & 117 & 133 & $160^{\mathrm{b}}$ & $203^{\mathrm{a}}$ & 5.1 & $<0.01$ & $<0.01$ & $<0.01$ \\
\hline$L$ & $0.87^{\mathrm{b}}$ & $0.97^{\mathrm{a}}$ & 0.001 & 0.001 & 0.001 & 0.001 & 0.90 & 0.93 & $0.77^{\mathrm{a}}$ & $0.61^{\mathrm{b}}$ & $1.98^{\mathrm{a}}$ & $1.64^{\mathrm{b}}$ & $0.58^{\mathrm{b}}$ & $0.65^{\mathrm{a}}$ & 0.017 & $<0.01$ & $<0.01$ & $<0.01$ \\
\hline \multicolumn{19}{|c|}{ Microbial protein synthesis } \\
\hline Purines & $22.8^{\mathrm{a}}$ & $16.0^{\mathrm{b}}$ & $8.9^{\mathrm{a}}$ & $6.5^{\mathrm{b}}$ & 12.2 & 9.7 & 14.3 & 12.7 & 22.3 & 19.0 & 11.3 & 10.4 & 20.0 & 8.5 & 2.05 & $<0.01$ & $<0.01$ & $<0.01$ \\
\hline EMPS & 34.0 & 22.0 & $21.4^{\mathrm{a}}$ & $11.2^{\mathrm{b}}$ & $14.5^{\mathrm{a}}$ & $8.5^{\mathrm{b}}$ & 27.6 & 23.2 & 32.5 & 30.4 & $28.6^{\mathrm{a}}$ & $21.2^{\mathrm{b}}$ & $38.4^{\mathrm{a}}$ & $14.6^{\mathrm{b}}$ & 5.90 & $<0.01$ & $<0.01$ & $<0.05$ \\
\hline PF & 2.8 & 2.6 & 2.9 & 2.5 & 3.3 & 2.8 & $2.6^{\mathrm{a}}$ & $1.9^{\mathrm{b}}$ & 2.9 & 2.6 & $5.7^{\mathrm{a}}$ & $2.9^{\mathrm{b}}$ & $3.4^{\mathrm{a}}$ & $1.7^{\mathrm{b}}$ & 0.08 & $<0.01$ & $<0.01$ & $<0.01$ \\
\hline True IVDMD & 546 & 579 & $270^{\mathrm{b}}$ & $352^{\mathrm{a}}$ & 479 & 526 & 379 & 391 & 481 & 461 & 470 & 463 & $338^{\mathrm{b}}$ & $545^{\mathrm{a}}$ & 28.2 & $<0.01$ & $<0.01$ & $<0.01$ \\
\hline ME & $8.3^{\mathrm{b}}$ & $9.2^{\mathrm{a}}$ & $5.0^{\mathrm{b}}$ & $6.8^{\mathrm{a}}$ & $6.4^{\mathrm{b}}$ & $7.8^{\mathrm{a}}$ & $5.5^{\mathrm{b}}$ & $6.9^{\mathrm{a}}$ & 6.9 & 6.9 & $3.7^{\mathrm{b}}$ & $6.7^{\mathrm{a}}$ & $5.8^{\mathrm{b}}$ & $7.6^{\mathrm{a}}$ & 0.04 & $<0.01$ & $<0.01$ & $<0.01$ \\
\hline
\end{tabular}

Means of PEG within shrub with different letters (a,b) differed at $\mathrm{P}<0.05$. ns: no significant difference (i.e., $\mathrm{P}>0.05$ ).

${ }^{a} b$ is the asymptotic gas production $(\mathrm{ml} / \mathrm{g} \mathrm{DM}), k$ is the rate of gas production $(/ \mathrm{h}), L$ is the initial delay before gas production begins $(\mathrm{h})$. 
confounding might occur when PEG is used, as a resulting increase on microbial biomass will be reflected as a reduction, or no change, in apparent IVDMD thereby suggesting no benefit of PEG on IVDMD.

Propionate contributes to the energy supply of the ruminants as the main gluconeogenic precursor because ruminants absorb only small quantities of glucose from the small intestine. The negative effect of $\mathrm{CT}$ on propionate yields has been reported in vivo (Waghorn et al., 1994) and in vitro (MacMahon et al., 1997). Addition of PEG increased (P<0.05) production of propionate (117\% and 105\% in C. parvifolia and A shaffneri, respectively) which is consistent with Burggraaf et al. (2008) in white clover when PEG was included to counter effects of condensed tannins. This elevation might indicate improvements in substrate utilization by ruminal microbiota.

The combination of in vitro gas production measurements with the concomitant quantification of the truly degraded substrate provides important information about partitioning of fermentation products (Blümmel et al., 1999). Diminished values of our PF agrees with previous work (Baba et al., 2002; Singh et al., 2005). Although it is desirable to have an increase in substrate degradability if effects of tannins are reduced by supplemental PEG, a simultaneous large increase in gas production could simply result in lower partitioning of nutrients to microbial protein synthesis, and a reduced PF (Makkar et al., 1998).

It has been suggested that gas production at $24 \mathrm{~h}$ is proportional to the amount of actually digested carbohydrates at maintenance ME intake, and highly correlated to the ME content of feedstuffs (Giger-Riverdan et al., 2000). Addition of PEG resulted in increased ME values, which agrees to those reported by Karabulut et al. (2006) and Salem et al. (2007) who indicated that PEG increased the ME content foliage from Lotus sp and a variety of browse tree leaves.

Differences in ME among feeds reflects variation in fermentable carbohydrates and available $\mathrm{N}$ among them. While fermentable carbohydrates tend to elevate rate of gas production, other factors decrease gas production by diverting carbon from gas to microbial protein (Menke and Steingass, 1988). In our study, the ME increase might be attributed simply to a shift in PF due to a lack of a relationship between gas production and true IVDMD. Nonetheless, except for $L$. tridentata which had a low ME of $5 \mathrm{MJ} / \mathrm{kg}$, all our shrubs can be considered a good source of ME (Abas et al., 2005) and with forages used in goat and sheep production (Khanum et al., 2007).

The reduction in EMPS when tannin-rich browse and herbaceous legumes are incubated in presence of PEG has been reported. For example, Klieve et al. (1996) stated that higher EMPS in the absence of PEG could be the result of secondary compounds which could act as anti-bacteriophages to reduce efficiency of ruminal fermentation. In contrast, addition of PEG decreased EMPS, probably due to the reduction of the negative effects of tannins which might result in improvements in the use of the consumed organic matter (Silanikove et al., 1996), toward production of gas and VFA (Baba et al., 2002; Getachew et al., 2002). Moreover, decreases in microbial efficiency as true ruminally degraded organic matter increases could indicate that factors other than availability of energy limited efficiency of microbial $\mathrm{N}$ production and that energy from organic matter fermentation was uncoupled from microbial growth (Oba and Allen, 2003). Differences among shrubs might have contributed to the overall elevated values of EMPS in our study compared to those reported by Getachew et al. (2000) and Salem et al. (2007).

\section{Conclusions}

The shrubs A. constricta, C. parvifolia and M. biuncifera can be utilized as CP and ME resources to support small ruminant nutrition practices in semiarid regions of North Mexico. Improvements in gas production, as well as VFA and ME with PEG, supports their neutralizing effect on tannins, but it results in diminished efficiency of microbial protein synthesis. Results indicate that parameters of gas production were only moderate predictors of the nutritive quality of our shrubs species, and the complexity of compounds other than tannins in browse species could have limited in vitro fermentation.

\section{Acknowledgements}

Scholarship provided by CONACYT (201282) to the first author is fully appreciated. Similarly, support from ANKOM Technology, Inc. (Macedon, NY, USA) is recognized. The authors acknowledge the Programa de Mejoramiento del Profesorado-SEP (México) for financial support for the project: Economic and productive impact of industrial byproducts and uncommon feedstuffs in ruminant feeds.

\section{References}

Abas, I., Özpinar, H., Can Kutay, H., Kahraman, R., 2005. Determination of the metabolizable energy (ME) and net energy lactation (NEL) contents of some feeds in the Marmara region by the in vitro gas technique. Turk. J. Vet. Anim. Sci. 29, 751-757.

Ammar, H., López, S., González, J.S., Ranilla, M.J., 2004. Tannin levels in the foliage of some Spanish Shrub species at different stages of development. In: Seminar of the Sub-Network on Nutrition of the FAO-CIHEAM Inter-Regional Cooperative Research and Development Network on Sheep and Goats, Hammamet (Tunisia), 8-10 November 2001, pp. 159-163.

AOAC, 1997. Official Methods of Analysis. Association of Official Analytical Chemists, Gaithersburg, MD, USA.

Baba, A.S.H., Castro, F.B., Ørskov, E.R., 2002. Partitioning energy and degradability of browse plants in vitro and the implications of blocking the effects of tannin by the addition of polyethylene glycol. Anim. Feed Sci. Tech. 95, 93-104.

Blümmel, B., Makkar, H.P.S., Becker, K., 1997. In vitro gas production: a technique revisited. J. Anim. Physiol. Anim. Nutr. 77, $24-34$. 
Blümmel, B., Aiple, K.-H., Steingass, H., Becker, K., 1999. A note on the stoichiometrical relationship of short chain fatty acid production and gas formation in feedstuffs of widely differing quality. J. Anim. Physiol. Anim. Nutr. 81, 157-167.

Blümmel, M., Karsli, A., Russell, J.R., 2003. Influence of diet on growth yields of rumen micro-organisms in vitro and in vivo: influence on growth yield of variable carbon fluxes to fermentation products. Brit. J. Nutr. 90, 625-634.

Burggraaf, V., Waghorh, G., Woodward, S., Thom, E., 2008. Effect of condensed tannins in white clover flowers on their digestion in vitro. Anim. Feed Sci. Tech. 142, 44-58

Camacho, L.M., Rojo, R., Salem, A.Z.M., Mendoza, G.D., López, D., Tinoco, J.L., Albarrán, B., Montañez-Valdez, O.D., 2010. In vitro ruminal fermentation kinetics and energy utilization of three Mexican tree fodder species during the rainy and dry period. Anim. Feed Sci. Tech. 160, $110-120$.

Cody, R.P., Smith, J.K., 1997. Applied Statistics and the SAS Programming Language, 4th ed. Prentice Hall, Inc, Upper Saddle River, NJ, USA.

France, J., Dijkstra, J., Dhanoa, M.S., López, S., Bannink, A., 2000. Estimating the extent of degradation of ruminant feeds from a description of their gas production profiles observed in vitro: derivation of models and other mathematical considerations. Brit. J. Nutr. 83, $143-150$.

Getachew, G., Makkar, H.P.S., Becker, K., 2000. Effect of polyethylene glycol on in vitro degradability of nitrogen and microbial protein synthesis from tannin-rich browse and herbaceous legumes. Brit. J. Nutr. 84, 73-83.

Getachew, G., Makkar, H.P.S., Becker, K., 2001. Method of polyethylene glycol application to tannin-containing browses to improve microbial fermentation and efficiency of microbial protein synthesis from tannin-containing browses. Anim. Feed Sci. Tech. 92, 51-57.

Getachew, G., Makkar, H.P.S., Becker, K., 2002. Tropical browses: contents of phenolic compounds, in vitro gas production and stoichiometric relationship between short chain fatty acid and in vitro gas production. J. Agric. Sci. 139, 341-352.

Giger-Riverdan, S.C., Maarouffi, C., Bontems, V., Jousse, C., 2000. Interest and limits of the HFT method to evaluate the energy value of compound feeds for small ruminants. Cah. Options Méditerr. 52, 39-42.

Hamid, P., Akbar, T., Hossein, J., Ali, M.G., 2007. Nutrient digestibility and gas production of some tropical feeds used in ruminant diets estimated by the in vivo and in vitro gas production techniques. Am. J. Anim. Vet. Sci. 2, 108-113.

INEGI, 2006. II Statistics on population and housing 2005. National Institute for Statistics, Geography and Computing, Mexico. D.F. Mexico.

Jones, R.J., Meyer, J.H., Becas, M., Stoltz, M.A., 2000. An approach to screening potential pasture species for condensed tannins activity. Anim. Feed Sci. Tech. $85,269-277$.

Karabulut, A., Canbolat, O., Kamalak, A., 2006. The effect of PEG on in vitro organic matter digestibility and metabolizable energy of Lotus corniculatus L. Lotus Newsl. 36, 7-10.

Khanum, S.A., Yaqoob, T., Sadaf, S., Hussain, M., Jabbar, M.A., Hussain, H.N., Kausar, R., Rehman, S., 2007. Nutritional evaluation of various feedstuffs for livestock production using in vitro gas method. Pak. Vet. J. 27, 129-133.

Khazaal, K.A., Parissi, Z., Tsiouvaras, C., Nastis, A., Ørskov, E.R., 1996. Assessment of phenolics-related antinutritive levels using the in vitro gas production technique: a comparison between different types of polyvinylpyrrolidone or polyethylene glycol. J. Sci. Food Agric. 71, $405-414$.

Klieve, A.V., Swain, R.A., Nolan, J.V., 1996. Bacteriophages in the rumen; type present, population size and implication for the efficiency of feed utilization. Proc. Aust. Soc. Anim. Prod. 21, 92-94.

Leinmüller, E., Menke, K.H., 1990. Tannins in feeds for ruminants. I Chemical properties and reactions with macromolecules. Übersichten zur Tierenahrung. $18,91-114$

MacMahon, L.R., Goto, M., Mc Allister, T.A., Jones, G.A., Cheng, K.J., 1997. Comparison of the in vitro fermentation characteristics of fractionated alfalfa and Sainfoin. In: Buchanan-Smith, J.G., Bailey, L.D., McCaughey, P. (Eds.), Proc. 18th Int. Grassl. Cong. session 8. Management Centre. Calgary, AB, Canada, pp. 15-16.

Makkar, H.P.S., Blümmel, M., Becker, K., 1995. Formation of complexes between polyvinyl pyrrolidones or polyethylene glycols and tannins, and their implications in gas production and true digestibility in in vitro techniques. Brit. J. Nutr. 73, 897-913.

Makkar, H.P.S., Blümmel, M., Becker, K., 1998. Application of an in vitro gas method to understand the effects of natural plant products on availability and partitioning of nutrients. Brit. Soc. Anim. Sci. Occ. Publ. No. 22. Brit. Soc. Anim. Soc. pp 147-150.

Makkar, H.P.S., 2003a. Effects and fate of tannins in ruminant animals, adaptation to tannins, and strategies to overcome detrimental effects of feeding tannin-rich feeds. Small Rumin. Res. 49, 241-256.

Makkar, H.P.S., 2003b. Quantification of Tannins in Tree and Shrub Foliage. A Laboratory Manual. Kluwer Academic Publishers, Dordrecht, The Netherlands

Markantonatos, X., Green, M.H., Varga, G.A., 2008. Use of compartmental analysis to study ruminal volatile fatty acid metabolism under steady state conditions in Holstein heifers. Anim. Feed Sci. Tech. 143, 70-88.

Menke, K.H., Steingass, H., 1988. Estimation of the energetic feed value obtained from chemical analysis and gas production using rumen fluid. Anim. Res Dev. 28, 7-55.

Min, B.R., Barry, T.N., Attwood, G.T., McNabb, W.C., 2003. The effect of condensed tannins on the nutrition and health of ruminants fed fresh temperate forages: a review. Anim. Feed Sci. Tech. 106, 3-19.

Monteforte-Briceño, G.E., Sandoval-Castro, C.A., Ramirez-Aviles, L., Capetillo-Leal, C.M., 2005. Defaunating capacity of tropical fodder trees: effects of polyethylene glycol and its relationship to in vitro gas production. Anim. Feed Sci. Tech. 123-124, 313-327.

Narvaez, N., Brosh, A., Pittroff, W., 2010. Seasonal dynamics of nutritional quality of California Chaparral species. Anim. Feed Sci. Tech. 158, 44-56.

Norman, H.C., Revell, D.K., Mayberry, D.E., Rintoul, A.J., Wilmot, M.G., Masters, D.G., 2010. Comparison of in vivo organic matter digestion of native Australian shrubs by sheep to in vitro and in sacco predictions. Small Rumin. Res. 91, 69-80.

Oba, M., Allen, M.S., 2003. Effects of diet fermentability of efficiency of microbial nitrogen production in lactating dairy cows. J. Dairy Sci. 86, $195-207$.

Parissi, Z.M., Papachristou, T.G., Nastis, A.S., 2005. Effect of drying method on estimated nutritive value of browse species using an in vitro gas production technique. Anim. Feed Sci. Tech. 123-124, 119-128.

Pinos-Rodríguez, J.M., Aguirre-Rivera, J.R., Mellado, M., García- López, J.C., Álvarez-Fuentes, G., Méndez-Villazana, J.C., 2007. Chemical and digestibility characteristics of some woody species browsed by goats in Central Mexico. J. Appl. Anim. Res. 32, $149-153$.

Pinto, R.R., Sandoval-Castro, C.A., Ramírez-Avilés, L., 2002. In vitro gas production of foliage and fruits of forage trees with and without added PEG. Brit. Soc Anim. Sci., 137.

Ramírez, R.G., Lara, J.A., 1998. Influence of native shrubs Acacia rigidula, Cercidium macrum and Acacia farnesiana on digestibility and nitrogen utilization by sheep. Small Rumin. Res. 28, 39-45.

Ramirez, R.G., 1999. Feed resources and feeding techniques of small ruminants under extensive management conditions. Small Rumin. Res. 34, 215-230.

Ramírez-Orduña, R., Ramírez, R.G., Ramírez-Orduña, J.M., Cepeda-Palacios, R., Ávila-Sandoval, J.M., 2003. Seasonal variation in nutrient content of shrubs from Baja California Sur, Mexico. Forest Farm Commun. Tree Res. Rep. 3, 13-16.

Salem, A.Z.M., Robinson, P.H., El-Adawy, M.M., Hassan, A.A., 2007. In vitro fermentation and microbial protein synthesis of some browse tree leaves with or without addition of polyethylene glycol. Anim. Feed Sci. Tech. 138, 318-330.

Sanon, H.O., Kaboree-Zoungrana, C., Ledin, I., 2008. Nutritive value and voluntary feed intake by goats of three browse fodder species in the Sahelian zone of West Africa. Anim. Feed Sci. Tech. 144, 97-110.

Silanikove, N., Gilboa, N., Perevolotsky, A., Nitsan, Z., 1996. Effect of a daily supplementation of polyethylene glycol on intake and digestion of tannincontaining leaves (Quercus calliprinos, Pistacia lentiscus and Ceratonia siliqua) by goats. J. Agric. Food Chem. 44, $199-205$.

Singh, B., Sahoo, A., Sharma, R., Bhat, T.K., 2005. Effect of polyethylene glycol on gas production parameters and nitrogen disappearance of some tree forages. Anim Feed Sci. Tech. 123-124, 351-364.

Steel, R.G.D., Torrie, P.A., 1980. Principles and Procedures of Statistics. McGraw-Hill, New York, NY, USA 
Udén, P., Robinson, P.H., Mateos, G.G., Blank, R., 2012. Use of replicates in statistical analyses in papers submitted for publication in Animal Feed Science and Technology. Anim. Feed Sci. Tech. 171, 1-5.

Van Soest, P.J., Robertson, J.B., Lewis, B.A., 1991. Methods for dietary, neutral detergent fiber, and non starch polysaccharides in relation to animal nutrition. Symposium: carbohydrate methodology, metabolism, and nutritional implications in dairy cattle. J. Dairy Sci. 74, 3583-3597.

Waghorn, G.C., Shelton, I.D., McNabb, W.C., MacCutcheon, S.H., 1994. Effects of condensed tannins in Lotus pedunculatus on its nutritive value for sheep 2. Nitrogenus aspects. J. Agric. Sci. 123, 109-119. 